\title{
PENGARUH PANJANG SALURAN TRANSMISI TERHADAP TEGANGAN LEBIH TRANSIENT YANG DISEBABKAN KARENA PROSES ENERGIZED PADA SALURAN TRANSMISI $500 \mathrm{KV}$
}

\author{
Yuniarto \\ Program Studi Diploma III Teknik Elektro \\ Fakultas Teknik Universitas Diponegoro
}

\begin{abstract}
Yuniarto, in this paper explain that the utility of high transmission line result in the transient over voltage in transmission-line will also increasingly higher, mainly for lightning and switching surge. Switching surge is a dominant factor to show up much transient over voltage in the transmission-line in the level of $230 \mathrm{kV}$ or higher, if it is compared with lightning surge. Switching surge is caused by single energized process, the process itself to energize a transmission line in no load condition with energy power through switch closure operation. The research was aiming at observing the influence of transmission-line length to transient over voltage that occurred at the energized process in $500 \mathrm{kV}$ transmission line Ungaran-Pedan, which used EMTP (Electromagnetic Transients Program) to simulate it. The result of simulation showed that the transient over voltage occurred along the transmission-line which caused the higher voltage increase, providing that the line is also longer.
\end{abstract}

Key word: over voltage, transient, EMTP

\section{PENDAHULUAN}

Tegangan lebih transien adalah tegangan yang mempuyai amplitudo sangat besar dan berlangsung sangat singkat, ysng disebabkan oleh surja hubung atau surja petir.

Surja hubung adalah gejala tegangan lebih transien yang disebabkan oleh operasi pensaklaran sedangkan surja petir adalah gejala tegangan lebih transien yang disebabkan oleh sambaran petir.

Surja petir merupakan faktor yang lebih dominan dalam menimbulkan tegangan lebih transien pada saluran transmisi dengan tingkat tegangan di bawah $230 \mathrm{kV}$, dibandingkan dengan surja hubung. Sedangkan pada level tegangan 230 $\mathrm{kV}$ ke atas surja hubung merupakan faktor yang lebih dominan dalam menimbulkan tegangan lebih transien dibandingkan faktor surja petir (Stevenson, 1996). Peristiwa surja hubung salah satunya disebabkan oleh proses pemberian tenaga (energized), yaitu proses mengaliri sebuah saluran transmisi dalam keadaan tanpa beban dengan sumber tegangan, melalui operasi penutupan saklar.

Tujuan dari penelitian ini adalah untuk mengetahui pengaruh panjang saluran transmisi terhadap tegangan lebih transien yang terjadi di sepanjang saluran transmisi pada saat terjadi proses pemberian tenaga dengan bantuan EMTP (Electromagnetic Transients Program).

EMTP adalah suatu program komputer terintegrasi yang didesain khusus untuk menyelesaikan permasalahan peralihan (transient) pada sistem tenaga listrik dengan parameter $\mathrm{R}, \mathrm{L}$, dan $\mathrm{C}$ terkonsentrasi (lumped), dan parameter $\mathrm{R}, \mathrm{L}$ dan $\mathrm{C}$ terdistribusi, atau kombinasi dari kedua rangkaian tersebut.
Penelitian yang berhubungan dengan tegangan lebih transient telah dilakukan oleh beberapa peneliti, diantaranya adalah :

- Dommel dan Herman (1996) di University of British Columbia mendesain dan mengembangkan sebuah program komputer untuk menyelesaikan permasalahan transien pada sistem tenaga listrik. Program komputer tersebut dinamakan EMTP (Electromagnetic Transients Program).

- Marti (1998) dengan metode Frequency Dependent Profile (FDProfile) melakukan kajian mengenai profile tegangan lebih transien pada saluran transmisi $230 \mathrm{kV}$ dan menyatakan bahwa tegangan lebih transien tersebut terjadi tidak hanya di ujung-ujung saluran tapi juga di sepanjang saluran transmisi dengan profil dan karakteristik tegangan yang berbeda-beda.

- Samiyono (2000) dengan menggunakan EMTP melakukan kajian tentang tegangan lebih transien karena surja hubung pada transformator $500 \mathrm{kV}$ di Ungaran dan menyimpulkan bahwa tegangan itu masih berada di bawah BIL

\section{MATERI DAN METODA PENELITIAN}

Ruang lingkup penelitian ini adalah mengkaji masalah pengaruh panjang saluran transmisi terhadap tegangan lebih transien akibat operasi pemberian tenaga pada saluran transimisi $500 \mathrm{kV}$ di saluran transmisi Ungaran-Pedan.

Pemberian tenaga dilakukan dengan menggunakan tegangan $500 \mathrm{kV}$. Proses switching terjadi selama 0,5 detik. Dengan demikian materi kajian dalam penelitian ini terdiri dari : 
- Pembuatan model saluran transmisi

- Penentuan nilai parameter saluran transmisi

- Penerapan model rangkaian ke dalam program EMTP

- Pengamatan hasil simulasi dari EMTP

Sedang metode penelitian ini adalah melakukan pendekatan terhadap keadaan yang sebenarnya ke dalam metode penyelesaian yang dipakai oleh EMTP. Data yang dipakai dalam penelitian ini diambil dari saluran transmisi Ungaran-Klaten. Diagrama alir dapat dilihat pada gambar 1.

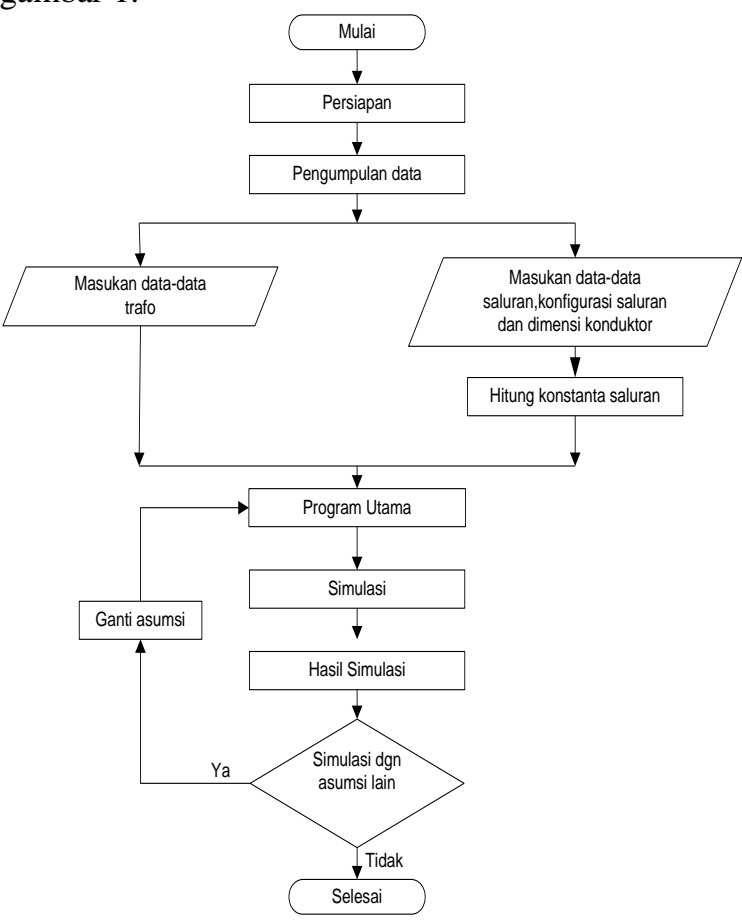

Gambar 1. Diagram Alir Jalannya Penelitian

\section{HASIL DAN PEMBAHASAN}

Penelitian ini mengasumsi beberapa hal antara lain :

- Parameter tersebar merata di sepanjang saluran transmisi

- Saluran transmisi ideal

- Saluran tidak memakai reaktor

- Pemutus tenaga menutup secara serentak

Penelitian dilakukan dengan memodelkan saluran transmisi $500 \mathrm{kV}$ pada keadaan tanpa beban, dengan panjang saluran 70,35 km dengan menggunakan EMTP. Kemudian dilakukan simulasi proses pemberian tenaga dengan cara menjalan program EMTP tersebut. Hasil yang ditampilkan pada simulasi ini adalah nilai-nilai tegangan yang terjadi pada tiap $10 \mathrm{~km}$ dari sumber tegangan pada saat pemberian tenaga di saluran transmisi tersebut. Sedangkan single diagram saluran transmisi $500 \mathrm{kV}$ Ungaran-Klaten adalah seperti terlihat pada gambar 2 .

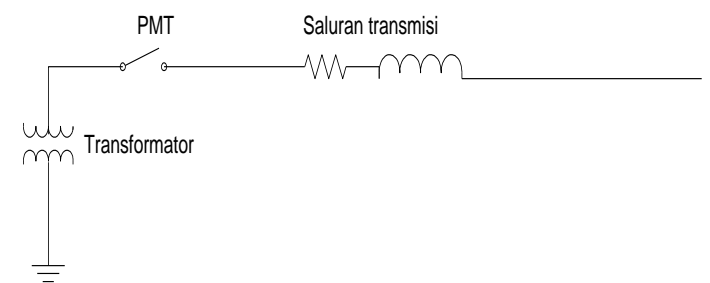

Gambar 2. Skema Saluran Transmisi UngaranKlaten

Jika saluran tersebut dimodelkan dengan menggunakan EMTP, maka gambar model rangkaianya adalah seperti terlihat pada gmbar 3 :

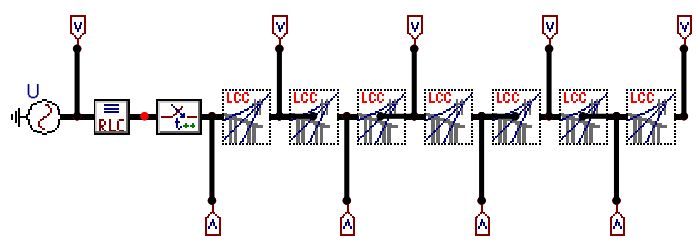

Gambar 3. Model Rangkaian untuk Simulasi

Dengan simulasi progam EMTP didapatkan grafik yang menggambarkan hubungan antara panjang saluran dengan tegangan lebih transient yang terjadi, seperti yang terlihat pada gambar 4 .

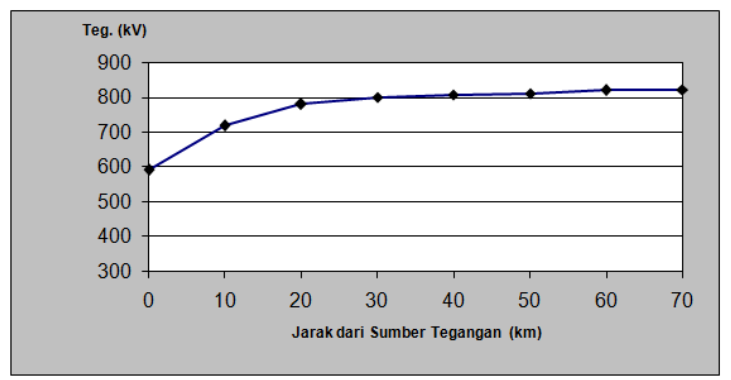

Gambar 4. Grafik Hubungan antara Jarak Pengukuran dengan Tegangan Lebih Transien.

Gambar 4 menunjukan bahwa tegangan lebih transient yang terjadi cenderung akan semakin besar jika panjang saluran transmisi juga semakin besar. Kecenderungan tersebut terlihat sekali pada jarak $0 \mathrm{~km}$ sampai $30 \mathrm{~km}$, tapi kecenderungan tidak begitu terlihat pada jarak $30 \mathrm{~km}$ sampai $70 \mathrm{~km}$ dan akan cenderung stabil jika jarak tersebut semakin besar.

\section{KESIMPULAN}

Kesimpulan yang dapat diambil dari penelitian ini adalah :

- Tegangan lebih transient yang timbul pada saat energized pada saluran transmisi $500 \mathrm{kV}$ Ungaran-Pedan terjadi di sepanjang saluran

- Besar tegangan cenderung semakin besar jika panjang saluran transmisi juga semakin besar. 
- Kecenderungan tersebut akan mengecil jika panjang saluran semakin besar lagi.

\section{Daftar Pustaka}

1. Dommel, dan Herman, W., 1996. Electromagnetic Transients Program, Vancouver, Canada.

2. EMTP Development Coordination group, 1998, The Electromagnetic Transients Program, Version 3,0 Rule Book 1, Volume 1, EPRI Report.
3. Galvan, A., and Cooroy, V., 1997, Analysis of Lightning-Induced Voltages in a Network of Conductors using the ATP-EMTP Program, Conference Publication no. 445, IEEE.

4. Marti, L., 1998, Calculation of Voltage profile Along Transmission Lines, IEEE on Transaction on Power Delivery.

5. Naidu, MS., V., Kamaraju, 1995, High Voltage Engineerin", Tata MCGraw-Hill Publishing Company Limited. 